\title{
Sciendo
}

\section{European Affiliations or National Interests? Analyses of Voting Patterns on Trade Policy in European Parliament ${ }^{1}$}

\author{
Yoo-Duk Kang \\ Language and Trade Division, \\ Hankuk University of Foreign Studies \\ Room 422, Main Building, \\ 107, Imun-ro, Dongdaemun-gu, \\ Seoul 02450, Republic of Korea \\ E-mail: ydkang@hufs.ac.kr
}

Abstract: This article examines the determinants of voting patterns within the European Parliament for EU trade legislations including EU trade agreements. Given that trade is a very sensitive issue for particular Member States, our question is to verify whether members of European Parliament (MEP) tend to vote in line with their political affiliation or national identity prevails in voting for trade-related issues. Our results from EU trade agreements with Korea and Columbia/Peru show that MEPs tend to vote with others in their political groups in trade legislations and their voting pattern is not very different from the overall voting pattern observed in other policy areas. This trend is confirmed by both the comparison of intra-voting cohesion index and the empirical test based on the probit model. Country-specific variables do not explain well the voting behavior of MEPs in trade issues. However, it is noteworthy that some MEPs voted in line with their national interests in case of EU-Korea FTA.

Keywords: European Parliament, free trade agreement, national identity, political affiliation, probit model, voting pattern

$\overline{1}$ This work was supported by Hankuk University of Foreign Studies Research Fund. 


\section{Introduction}

The Lisbon Treaty has brought about considerable changes in the European Union (EU) trade policy by strengthening the role of the European Parliament (EP). The Treaty enhanced the status of the EP as a genuine actor in EU trade policy making. The Commission is now under legal obligation to "report regularly $[\ldots]$ to the European Parliament on the progress of negotiations". In addition, the EP now has the formal right to give a consent to trade agreements that the EU concludes with third countries and the EU trade-related legislation follows ordinary legislative procedure (OLP), better known as the 'co-decision procedure'. Given that the OLP involves both the Council and the EP as joint decision-makers, the role of the EP is no longer a consultative institution, but a main player in trade policy.

Since then, the EP has been invested with the 'hard power' of consent in the ratification phase of trade agreements, which gives it sufficient leverage to influence trade negotiations. Applying the OLP in trade-related legislations means that the EP is more involved in EU trade policy both in terms of expansion (market access) and defense (safeguard). While the Treaty does not grant any formal powers to the EP in the drafting of negotiation directives, the EP can develop strategies to influence the mandate (Hix \& Høyland, 2013; Héritier, 2015). For instance, the EP previously voiced its opinions with regard to trade negotiations in progress. These opinions were legally non-binding during the pre-Lisbon era, and the Commission was relatively free to consider it or to leave it out (Krajewski, 2005, p. 97; Van den Putte et al., 2014, p. 4). However, the EP has since been endowed with 'veto power' to the final result of negotiations, and the Commission is thus obliged to incorporate the EP's view into its negotiation agenda. In February 2010, the EP used this new power and rejected the initial verison of the SWIFT agreement, showing that the EP was ready to use its veto power against an international agreement (Wolfstädter et al., 2018).

Is this new reality affecting voting patterns of the EP? There has been a consensus in academic circles that transnational-European-party group affiliations are more important than national affiliations for determining how a member of the European Parliament (MEP) votes. For instance, Noury and Roland (2002) estimate that if one knows which political group an MEP belongs to, one could correctly predict his/her voting behavior $90 \%$ of the time. An increasing number of studies agree that political group affiliation is the main voting determinants for MEPs with party cohesion in the EP steadily increasing in line with the 
expanding role of the EP over time (Hix, 2001; Hix \& Noury, 2009a; 2009b; Ringe, 2010; Hix \& Høyland, 2011).

However, when voting on trade-related issues, particularly for trade agreements with third countries, it is doubtful whether European party affiliation and allegiance would be decisive factors in explaining the voting of individual MEPs.

This question arises from the voting on the EU-Korea Free trade agreement (FTA) and the bilateral safeguard clause in the EU-Korea FTA. The former involved questions of granting consent to EU trade deals for the first time since the Lisbon Treaty, while the latter concerned voting on regulations in the OLP. The two voting sessions are legally separate issues, but they were both carried out on February 11, 2011. This FTA is unique in two aspects; first the FTA is EU's first trade deal with third countries under the well-known 'Global Europe' (European Commission, 2006). The Commission had been negotiating the same types of trade agreements - in terms of coverage and depth - with other trading partners such as India, Singapore and Canada. So the EP's votes on the EUKorea FTA could send a strong signal as to what the EP wants in other FTA negotiations. Second, the FTA was EU's first trade deal to be ratified under the Lisbon Treaty. In this context, the result of the FTA vote was the first experiment on how the EP exerts its new power in the ratification of trade agreements. Figure 1 illustrates the voting result of the FTA: 465 MEPs voted in favor of the FTA while 128 MEPs were against, with 9 abstentions. The largest political group in the EP, European People's Party (PPE) showed its strong and cohesive support for the FTA. All its MEPs voted in favor of the FTA (214 votes) with only one blank ballot. The second largest political group, European Socialist Party (PES, currently renamed as S\&D) was generally friendly toward the FTA. Its 133 members approved the FTA, while a minority of 25 members chose to vote against it. However, it seems that the MEPs of the PES were divided, at least partially, along with the national line. All French (13 members) and two-thirds of Italian MEPs (12 members) voted against the FTA, whereas all German MEPs (21 members) voted in favor of the FTA as illustrated in Figure 2. This diverging pattern reflected, in fact, the interests of national industries, particularly that of the auto industry. It is well-known that the European auto industry was opposed to the FTA from the beginning (ACEA, 2009). 
Figure 1. Distribution of votes for EU-Korea FTA in the European Parliament

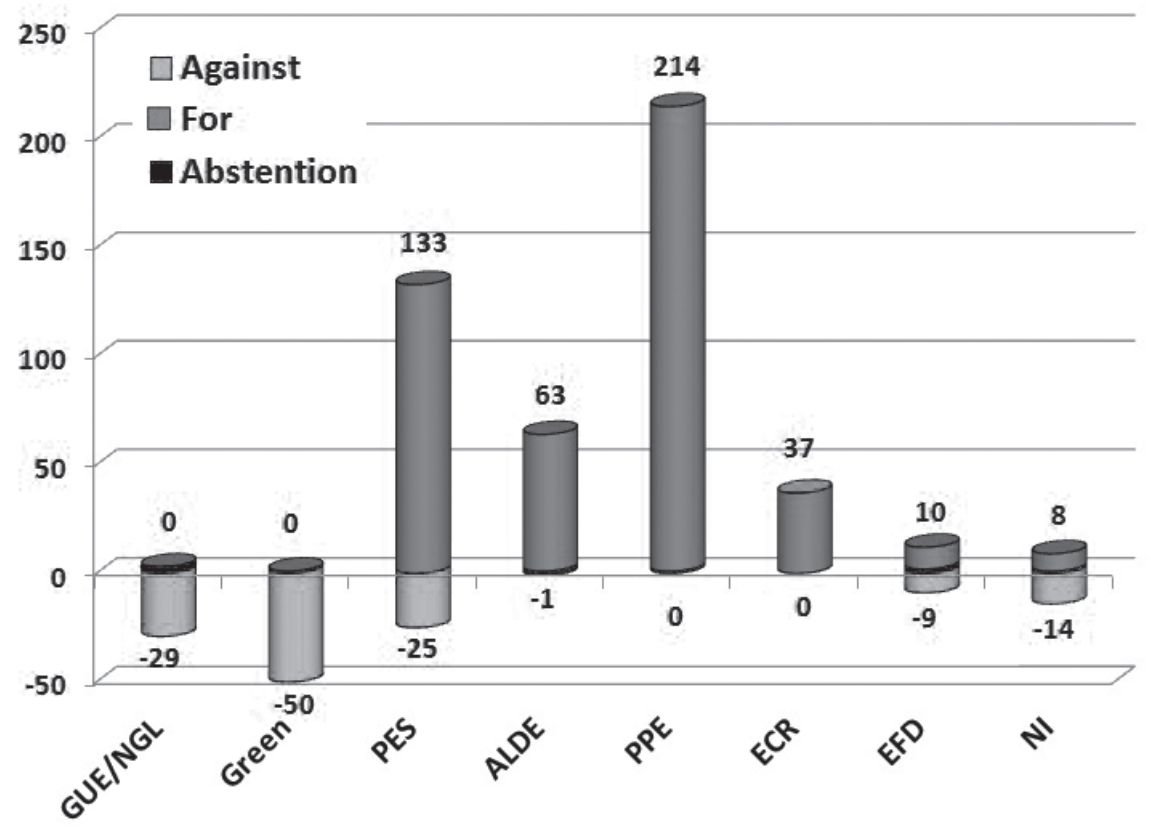

Source: VoteWatch.eu

This case calls into question the well-established factual argument-MEPs tend to vote along with their European party affiliations. In this paper, we try to reexamine this argument as it relates to the trade policy area. Our question is whether there are any particular factors affecting MEPs' voting decisions in trade-related legislations, particularly when the latter might have different impact on national industries. If there exists a particular pattern of voting in trade issues, such a pattern may be more salient in the future in that the EP has been in the process of learning how to translate its newly-obtained power into a concrete trade agenda. In order to analyze voting patterns of the EP in trade-related issues, we select the most representative voting sessions in the post-Lisbon era and try to find how different factors, such as European political groups or national party affiliation, and national variables, affect voting decisions of MEPs. Given that there is no empirical study on voting patterns of the EP in trade issues yet, we expect our study to contribute to analyzing the EP's voting behavior further and nurturing empirical studies in this field.

The remainder of this paper is organized as follows. The second section is an overview of previous studies on voting patterns of the EP in general for which 
Figure 2. Distribution of votes within the PES for EU-Korea FTA

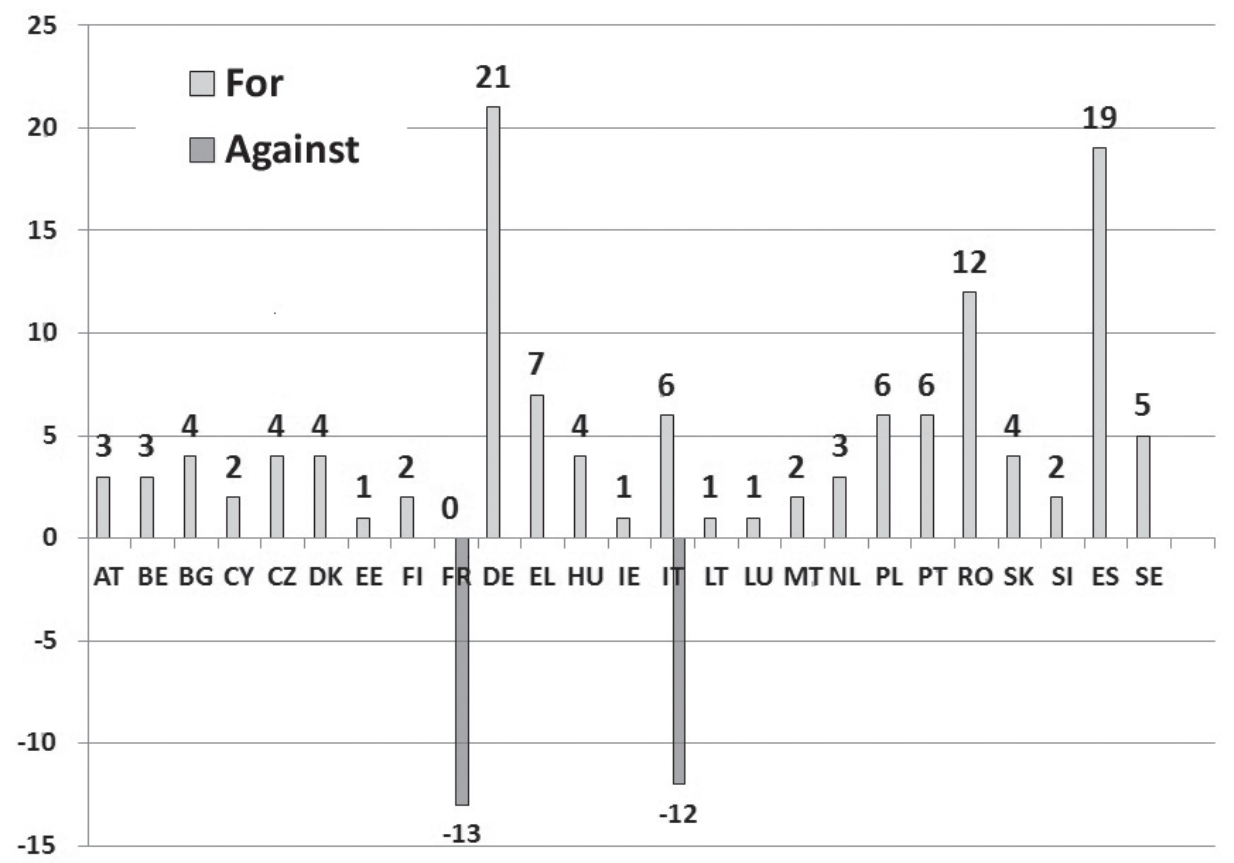

Source: VoteWatch.eu

there are already sufficient number of empirical cases. We pay particular attention to studies on US congressional voting patterns for comparative purposes. The third section describes changes brought about by the Lisbon Treaty in the trade policy area. We examine particularly changes in the role of the EP in the EU trade policy making process. In the fourth section, we conduct empirical analysis on the determinants of voting patterns for selected cases. Finally, the fifth section summarizes the analyses and opens a door to further studies.

\section{The role of European Parliament in the EU trade policy}

\subsection{EU trade policy and the EP's involvement}

Trade policy has been developed as an exclusive competence of the EU. The latter is responsible for trade policy and agreements with third countries. EU trade policy areas fell into two categories, areas under EU's exclusive competence and those for which the EU share competences with Member States. The EU, represented by the European Commission, takes charge of the package 
of trade deals. However, the EU shared competences with its Member States in trade in service, investment and intellectual property rights. Due to this divided nature of competences, a trade agreement with third countries generally required a ratification process in national assemblies of Member States after a formal approval from the Council and the assent of the EP. This complexity gave birth to provisional application for most of EU's trade agreements.

The EP had been specifically excluded from consultation on trade agreements. It was consulted on other trade agreements on investment and services which fall under provisions of Article 300. But it is well known that this was nonbinding consultation. The role of the EP in trade policy was described as that of a "privileged lobbyist": the MEP has access to documents, but the Commission reserved the right to take EP's views into account or exclude them (Reichert, 2004).

\subsection{Changes in EP's competences after the Lisbon Treaty}

The Lisbon Treaty aims to ensure that the EU remains effective in its policymaking and consolidates the political aspects of integration following the enlargement. The Treaty gives rise to various changes in the functioning of European institutions and decision-making processes. Particularly, it brings about considerable changes in EU trade policy as follows.

First, the Treaty streamlines EU's trade policy by confirming that all key aspects of trade policy are now explicitly an exclusive EU competence. EU competence is extended to all services, trade-related intellectual property rights and, in a major innovation, to foreign direct investment (FDI). In consequence, the EU can negotiate comprehensive agreements covering trade and investment with third countries. However, certain specific areas, such as cultural and linguistic diversity and effective national health, education and social policies are excluded from EU competence. Second, regulations defining the framework for implementing EU trade policy are under the ordinary legislative procedure (OLP) in the legislative process, de facto co-decision procedure. The EP shares powers with the Council to adopt regulations on trade issues such as Generalized Systems of Preferences (GSP) and amendments to market access regulations concerning EU's Economic Partnership Agreements (EPAs). Under the Lisbon Treaty, the EP has actual powers to shape the content of the regulations, although it is the Commission who still conducts trade negotiations with third parties in close steering consultation with the Council. 
Figure 3. EU's decision-making process on external trade policy

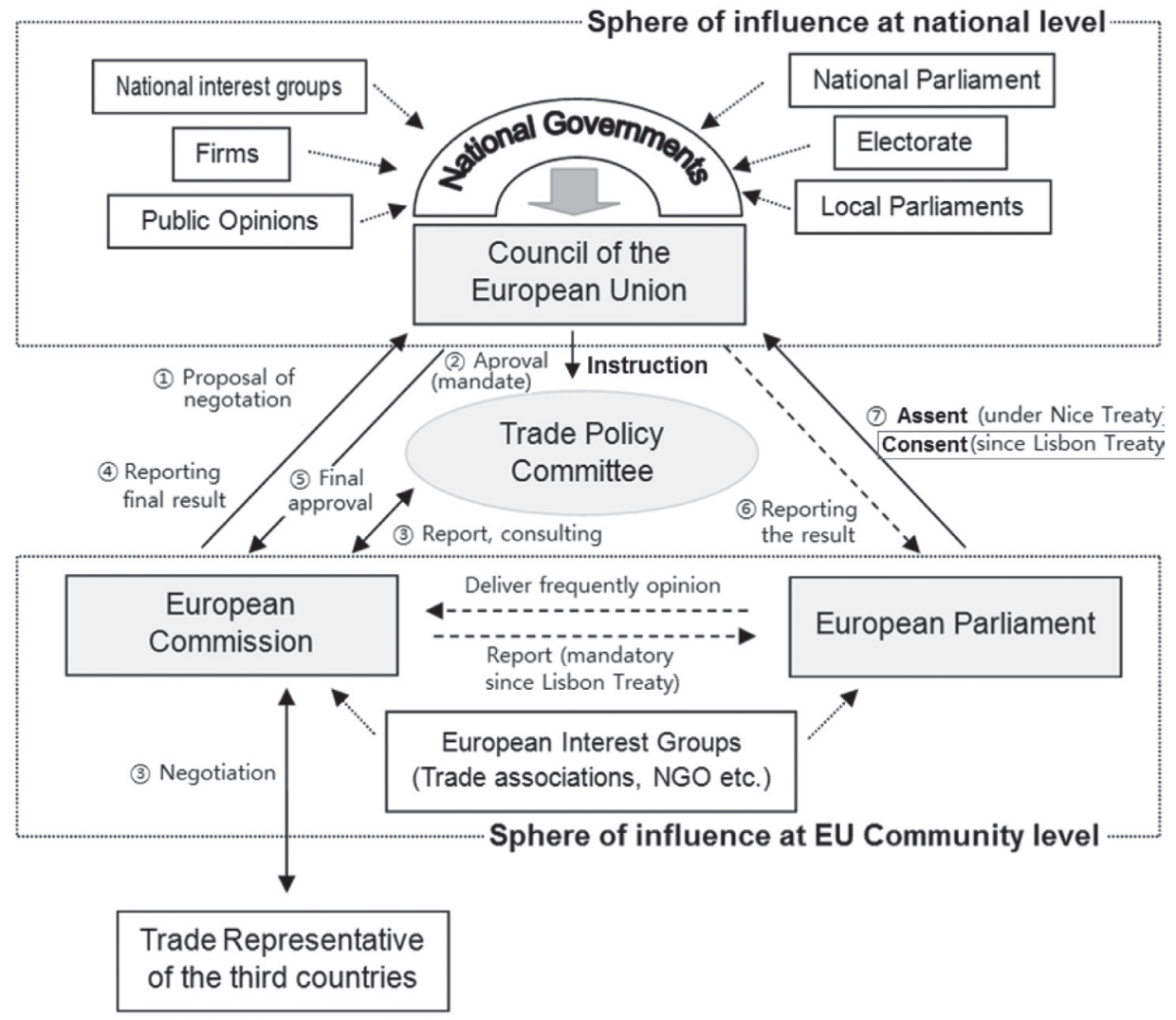

Third, the Commission will be formally obliged to consult with the EP on the conduct of negotiations. Now, International Trade Committee (INTA) of the EP receives the same information as the Council's Trade Policy Committee.

Finally, the EP now reserves the right to grant its consent to the adoption of the results of trade negotiations as a whole. Article 218 states that all decisions where OLP applies for implementation should acquire consent from the EP in order to be adopted definitively. Figure 3 illustrates the trade policy making process at the EU level and stakeholders either directly or indirectly involved. Traditionally, the two most important actors were the European Commission and the Council. Trade negotiations with third countries start by a proposal initiated by the Commission (1). After the Council authorizes the proposal, investing a negotiating mandate to the Commission (2), the latter negotiates agreements in consultation with the Trade Policy Committee (3) under the control of the Council. When the Commission finalizes the negotiation with the third country (4)), the Council approves the results by qualified majority (5). 
It is from this phase that the role of the EP has been changed. Since the Lisbon Treaty, the EP is called upon to give its consent to the trade agreements, meaning that the EP has the decisive last word, equivalent to an approval/veto of the agreement. Besides, the Commission must inform the EP in detail regarding the contents of negotiations under way. This is a considerable change in EU trade policy making procedure in that the EP can develop some creative measures to influence the negotiations. For instance, the EP can announce a resolution on a particular trade negotiation under way. Despite the non-binding nature of the resolution, the Commission is obliged to respect the resolution and reflect its contents on the negotiation agenda as much as possible, because the EP has de facto veto power with respect to the final result of negotiations. In addition, it also means that lobbying from various interest groups to MEPs in trade issues will increase considerably.

\section{Literature review of voting patterns of European Parliament}

\subsection{The voting patterns of European Parliament}

The role of the EP in the legislative process has expanded steadily over time as the scope of EU policy has grown. Initially, the EP was limited to offering non-binding opinions in a 'consultation procedure'. The EP began to gain more power to affect EU legislation in the 'cooperation procedure' by the Single European Act and the 'co-decision procedure' by the Maastricht Treaty. Faced with recurrent criticism of 'democratic deficit' in EU governance and growing competences at the EU level, reforms has been carried out towards increasing the power of the EP, the only European institution established by direct election.

With increasing involvement of the EP in EU's legislative procedure, MEPs' voting pattern or leading factors in voting decisions attracted academic attention. Assuming that MEPs experience tension between national interests or allegiance over their political affiliations in the EP, most studies have focused on how much MEPs overcome their national lines over political preferences-ideologyand transnational-European-party discipline. ${ }^{2}$ The latter was considered as an important factor in that the EP should enhance itself from a chamber of representatives of national interests to a genuinely politicized parliament.

Most of MEPs are obliged to take into account multiple factors such as their personal policy preference, electorate in the home country, national party and

2 Party discipline refers to the ability of a parliamentary group to induce its members to support the policies of their group's leadership. 
Figure 4. Changes in political group and Member States cohesion

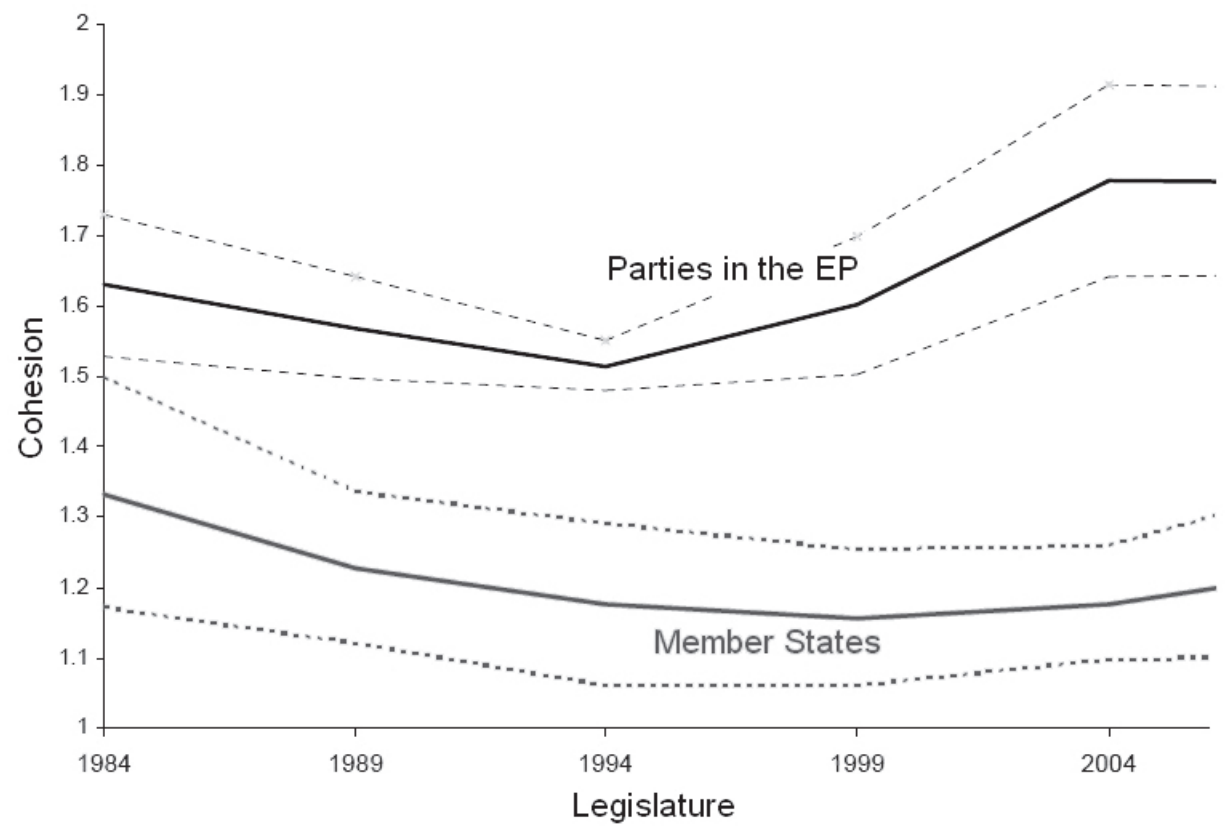

Note: The figure shows the average of 'relative cohesion' of the parties in each parliament plus the first 18 months of the 6th EP (2004-09) relative to the average relative cohesion of each national groups of MEPs in the same period. The dotted lines represent the standard deviations around these averages.

The formula (Agreement Index, Al) is as follows:

$$
\mathbb{A}_{i}=\frac{\max \left\{Y_{i}, N_{i}, A_{i}\right\}-0.5\left[\left(Y_{i}+N_{i}+A_{i}\right)-\max \left\{Y_{i}, N_{i}, A_{i}\right\}\right]}{\left(Y_{i}+N_{i}+A_{i}\right)}
$$

Source: Hix \& Noury, 2006

political membership in the EP. Facing a high number of political parties, a variety of decision rules and multiple influences, MEPs have to answer to two different principals - the national party, who controls the selection of candidates in EP elections, and political groups in the EP, who control a variety of private goods in the EP, such as leadership positions, committee assignments, speaking time and legislative agenda (Hix, 2002). These principals collide when MEPs must take one of two positions - national lines or political affiliations.

The findings in studies conducted in the 1990s support a clear conclusion-when MEPs attend plenary sessions, they vote largely with others in their European party group. The evidence for this conclusion was the growing level of intravoting 'party cohesion', examined by Attinà (1990), Brzinski (1995), and Hix (2000). 
Figure 5. Cohesion patterns of European political groups

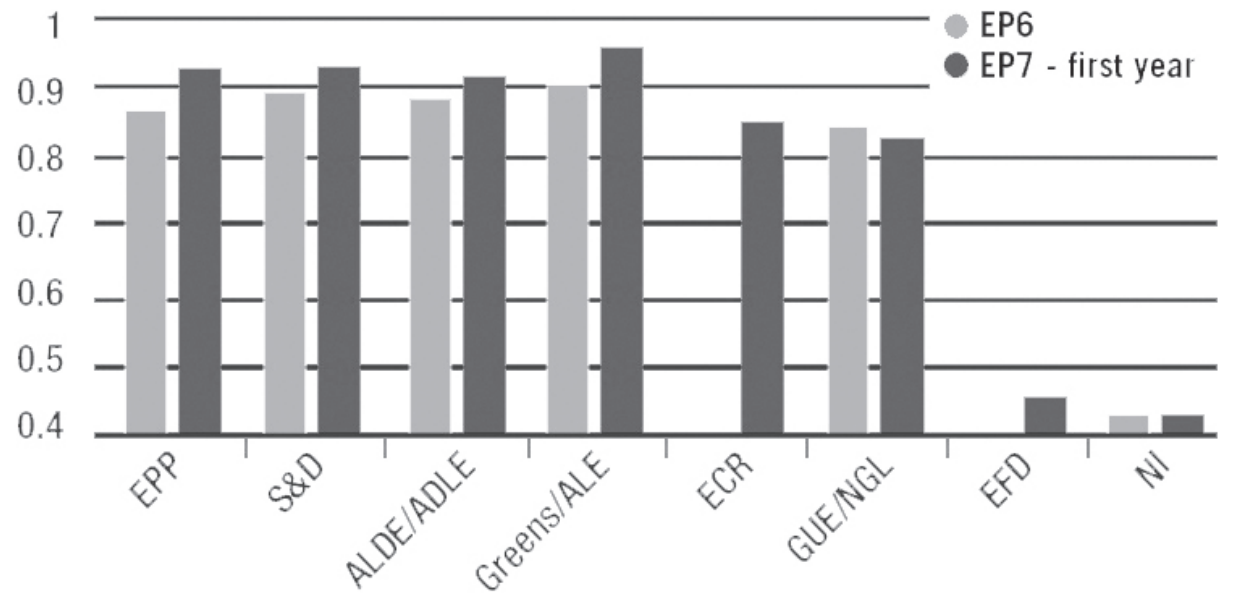

Note: 'Agreement Index' for each European political group according to Hix and Noury (2006) formula.

Source: VoteWatch, 2010

There is rather a consensus in academic circles that European party group affiliations are much more important than national affiliations for determining how the MEP votes. It has also been shown by various studies in the 2000 s that national loyalties have considerably less important impact on the MEP's voting behavior than the EP party affiliation. In other words, ideology-driven voting has been taking clear priority over voting by nationality in MEPs' voting patterns (Gabel \& Hix, 2007; Hix, 2001; Hix \& Noury, 2009a; 2009b; Hix, Noury \& Roland, 2007; Roland, 2009). This voting pattern received positive appraisals from both academic and political societies at the EU level. After the enlargement of the EU in the mid 2000s, MEPs tend to vote even more in line with their political affiliation in the EP rather than along national lines. VoteWatch (2010) reports that MEPs vote mainly along the transnational political lines rather than along national lines. MEPs' intra-voting cohesion rates of four largest political groups have been growing and is even higher than the cohesion scores of Member States. 


\subsection{US congressional voting on trade policy}

Research on voting behavior within the EP builds upon previous empirical studies on the US Congress that exerted its decisive power in US trade policy. For example, Hiscox (2002) examines congressional votes of major trade legislations using the probit model. His approach is based on the presumption that legislators' voting decision reflects pressures from their constituency and societal groups. The author concludes that policy-makers aim to capture support from a broad class-based coalition and as a result, they are more inclined to adopt incoherent policy position that balance competing demands from the most powerful industry groups on both sides (in favor of or against free trade).

Baldwin and Magee (2000) examine determinants of congressional voting for NAFTA, GATT and the Fast-Track bill. Using the tobit model, they include as explanatory variables ideology, campaign contributions, and industrial structures of constituencies. They find that political preference and economic factors played a role in determining voting patterns on trade bills in the 1990s. Pro-business policy-makers tended to vote in favor of trade liberalization. Economic situations of legislators' district or states appeared particularly decisive in shaping voting decisions.

Xie (2006) examines the congressional voting on bills revoking or attaching conditions to China's most favored nation (MFN) trade status in the period of 1990-2001. His study focuses on how party status, partisanship, and economic conditions of policy-makers' districts influence voting decisions in congress. The study finds that party status and ideology are influential factors in explaining voting patterns of congressmen, while economic conditions are not much important as determinants of voting.

Lim and Sung (2011) analyze determinants of voting in the 108th and 109th Congress over FTAs that US concluded with its trade partners. Based on a simultaneous probit-tobit model, their model includes a wide range of explanatory variables such as campaign contributions, political inclination, assigned committees, and economic and population structures of districts. They find that party affiliation is a very influential determinant, particularly when margins in the roll-call results are narrow. They also find that a representative is less likely to approve FTAs, if he/she is from a district with a high level of unemployment and a high share of employment in industries sensitive to trade liberalization.

Despite the relatively well-documented studies on voting patterns in the US Congress in trade policy, the number of studies on voting patterns of the EP is very small. It seems that there are three reasons for that. First, the EP's role in 
the making of EU trade policy was very small relative to the US Congress in US trade policy. For this reason, it is difficult to find any EU trade legislation which politicized the EP. Second, EP's proportional election makes it difficult to clarify a traditional influence channel from the electorate to the individual MEP. Third, the EP's proportional representation system makes it difficult to attempt empirical studies on determinants of voting patterns compared to the single member constituency system widely adopted in national parliamentary elections. All MEPs from a given Member State would have same national features, which render impossible studies based on the features of each MEP's constituency. This is why most of the studies focus on how MEPs vote cohesively rather than on the character of individual MEPs and the situation of their electorates.

\section{Econometric analyses}

We focus on the EP's votes on legislation during its 7th Parliament between July 2009 and December 2012. The 7th EP voted on 2,474 legislations during this period, which include drafts in the consultation and OLP, amendment of existing legislations and consents on international agreements as well as non-binding resolutions. The EP's voted on legislation in trade policy areas 113 times during the period. Most of the legislations were voted on under the Lisbon Treaty which came into effect in December 1, 2009. In this section we select representative examples of EU's trade legislations which required EP's ratification (consent) or co-decision (OLP) under the Lisbon Treaty. We suppose that there are three factors in general which play determinant roles in MEPs' voting decision as illustrated in Figure 6: (1) European/transnational party affiliation (party discipline), (2) national party affiliation; and (3) economic conditions of MEPs' home countries. We attempt to find the degree to which voting patterns of MEP in trade policy conform to or differ from the widely accepted trend that MEPs vote in line with their political groups in the EP.

\subsection{Trade legislations examined}

In order to analyze MEPs voting pattern in trade policy, we divided EU's trade legislations into three groups as follows:

Group 1: legislations for trade liberalization such as consent on an FTA;

Group 2: those for protecting domestic industries from international competition such as safeguard regulations; and

Group 3: nominal and less binding regulation or resolution related to trade. 
Table 1. Party group 'cohesion' in the European Parliament

\begin{tabular}{|l|c|c|c|c|c|c|c|c|}
\hline & \multicolumn{2}{|c|}{ Share of Seats in the EP (\%) } & \multicolumn{4}{c|}{$\begin{array}{c}\text { Voting Cohesion } \\
\text { (Index of Agreement) }\end{array}$} \\
\hline $\begin{array}{l}\text { Party Groups from } \\
\text { left to right (group } \\
\text { abbreviations in } \\
\text { brackets) }\end{array}$ & EP2 & EP3 & EP4 & EP5 & EP2 & EP3 & EP4 & EP5 \\
$(1984)$ & $(1989)$ & $(1994)$ & $(1999)$ & $\begin{array}{c}(1984- \\
89)\end{array}$ & $\begin{array}{c}(1989- \\
94)\end{array}$ & $\begin{array}{c}(1994- \\
99)\end{array}$ & $\begin{array}{c}(1999- \\
04)\end{array}$ \\
\hline Communists (LU) & - & 2.7 & - & - & - & 93.8 & - & - \\
\hline $\begin{array}{l}\text { Radical Left (EUL, } \\
\text { EUL/NGL) }\end{array}$ & 9.4 & 5.4 & 4.9 & 6.7 & 71.2 & 92.3 & 83.8 & 61.4 \\
\hline Greens (G) & - & 5.8 & 4.1 & - & - & 87.5 & 85.2 & - \\
\hline $\begin{array}{l}\text { Regionalists / Green \& } \\
\text { Regionalists (ERA, G/ } \\
\text { EFA) }\end{array}$ & 4.6 & 2.4 & 3.4 & 7.7 & 67.8 & 69.5 & 98 & 75.4 \\
\hline $\begin{array}{l}\text { Socialists \& Social } \\
\text { Democrats (PES or } \\
\text { S\&D) }\end{array}$ & 30 & 34.7 & 34.9 & 28.8 & 62.2 & 78.6 & 89 & 84.8 \\
\hline Liberals (ELDR) & 7.1 & 9.5 & 7.6 & 8.1 & 69.5 & 85.7 & 80.1 & 87.8 \\
\hline $\begin{array}{l}\text { Christian Democrats \& } \\
\text { Conservatives (EPP) }\end{array}$ & 25.3 & 23.4 & 27.7 & 37.2 & 84.1 & 88.2 & 90.2 & 81.1 \\
\hline $\begin{array}{l}\text { Nationalist- } \\
\text { Conservatives (EDG) }\end{array}$ & 6.7 & 3.9 & 9.4 & 4.8 & 75.7 & 64.5 & 93.2 & 58.3 \\
\hline $\begin{array}{l}\text { British Conservatives } \\
\text { (EDG) }\end{array}$ & 11.5 & 6.6 & - & - & 82.9 & 92.2 & - & - \\
\hline $\begin{array}{l}\text { Anti-Europeans (EN, } \\
\text { EDD) }\end{array}$ & - & - & 3.4 & 2.6 & - & - & 70.7 & 40.5 \\
\hline European Right (ER) & 3.7 & 3.3 & - & - & 96.1 & 99.9 & - & - \\
\hline Non-attached MEPs & 1.6 & 2.3 & .8 & 4.2 & - & - & - & - \\
\hline
\end{tabular}

Note: An Index of Agreement (IA) is a measure of the relationship between the three modalities of votes cast by the members of a party group ('yes', 'no', and 'abstain'), in relation to the total number of votes cast by the members of the group. The equation for calculating IA as following.

$$
I A=\frac{\text { (Highest modality }- \text { Sum of the other two modalities) }}{\text { Total number of votes cast by the party group }} \times 100
$$

The index is equal to 100 if all the members of the group vote the same way in every vote, and is equal to 0 if exactly half the members of a group vote one way and the rest vote another way in every vote.

Source: Calculated from data in Attina, 1990; Raunio, 1996; Hix and Lord, 1997, and Hix, 2000, recited from Hix, 2002 
We examined representative legislations of Group 1 and Group 2. For Group 1, we chose two EU votes (consent) on FTAs - the EU-Korea FTA and EUColombia/Peru FTA. For Group 2, we selected EU's three safeguard regulations related to the implementation of the EU-Korea FTA and to imports of bananas from Central America and Colombia/Peru. These regulations aim at protecting European industries, when imports from FTA partners abruptly increase to such an extent as to threaten domestic interests. We analyzed voting patterns of the EP on these two categories of trade legislations by using two methods. First, we examined distributions of votes along with European political parties and national lines in order to verify how much each MEPs vote in accordance with their parties' position. Second, using the probit model, we conducted empirical tests on these trade legislations with relevant variables which can affect voting decisions of MEPs.

Table 2. List of EP voting on trade legislation

\begin{tabular}{|c|c|c|c|}
\hline & Legislation & EP's role (date) & Result \\
\hline \multirow{2}{*}{$\begin{array}{l}\text { Trade } \\
\text { liberalization }\end{array}$} & EU-Korea FTA & $\begin{array}{c}\text { Consent } \\
\text { (February 17, 2011) }\end{array}$ & $\begin{array}{c}\text { Approved } \\
\text { (Yes: 465, No: 128, } \\
\text { Abstentions: 19) } \\
\end{array}$ \\
\hline & $\begin{array}{c}\text { EU-Colombia/Peru trade } \\
\text { agreement }\end{array}$ & $\begin{array}{c}\text { Consent } \\
\text { (December 11, } \\
\text { 2012) } \\
\end{array}$ & $\begin{array}{c}\text { Approved } \\
\text { (Yes: 486, No: 147, } \\
\text { Abstentions: 41) } \\
\end{array}$ \\
\hline \multirow{3}{*}{ Protectionism } & $\begin{array}{l}\text { Safeguard clause in EU-Korea } \\
\text { FTA }\end{array}$ & $\begin{array}{l}\text { OLP/Co-decision } \\
\text { (February 17, 2011) }\end{array}$ & $\begin{array}{c}\text { Approved } \\
\text { (Yes: 495, No: 16, } \\
\text { Abstentions: } 75 \text { ) }\end{array}$ \\
\hline & $\begin{array}{l}\text { Implementation of the bilateral } \\
\text { safeguard clause for bananas } \\
\text { of the EU-Colombia/Peru trade } \\
\text { agreement }\end{array}$ & $\begin{array}{l}\text { OLP/Co-decision } \\
\text { (December 11, } \\
\text { 2012) }\end{array}$ & $\begin{array}{c}\text { Approved } \\
\text { (Yes: } 569, \text { No: } 47, \\
\text { Abstentions: } 61 \text { ) }\end{array}$ \\
\hline & $\begin{array}{l}\text { Safeguard clause for bananas } \\
\text { of the EU-Central America } \\
\text { association agreement }\end{array}$ & $\begin{array}{l}\text { OLP/Co-decision } \\
\text { (December 11, } \\
\text { 2012) }\end{array}$ & $\begin{array}{c}\text { Approved } \\
\text { (Yes: } 579, \text { No: } 42, \\
\text { Abstentions: } 59 \text { ) }\end{array}$ \\
\hline
\end{tabular}

\subsection{Votes by political groups and countries}

We examined the distribution of votes according to European political groups. For the two FTAs, MEPs were largely divided into two groups, in favor of or against the FTAs, but tended to vote clearly along with their European political groups. In left-leaning parties, such as the GUE-NGL and Green/EFA, most 
MEPs voted against the FTAs and vote defection was rare. Most of the MEPs of the PES (center-left) voted in favor of the FTAs, showing a high level of intra-voting cohesion, while there are some MEPs who voted against the FTAs. These minority votes in the PES did not overturn the general trend of voting cohesion. However, they did attract attention in that the PES is composed of well-established socialist parties from each Member State and is the second largest group in the EP. Among center and right parties, MEPs of ALDE, EPP and ECR voted in line with their parties' dominant position, while only one party, the EFD, showed a high level of minority votes (EU-Korea) or did not require its members to vote in line with particular discipline (EU-Colombia/ Peru). One of the reasons is that the EFD was only formed in 2009 and includes very disparate national political groups dominated by euro-skeptics.

Table 3. Votes by political groups in the EP for the FTAs

\begin{tabular}{|l|c|c|c|c|c|c|c|c|c|c|}
\hline & For & Against & $\begin{array}{c}\text { Absten- } \\
\text { tions }\end{array}$ & $\begin{array}{c}\text { EP } \\
\text { position }\end{array}$ & $\begin{array}{c}\text { Co- } \\
\text { hesion } \\
\text { index }\end{array}$ & For & Against & $\begin{array}{c}\text { Absten- } \\
\text { tions }\end{array}$ & $\begin{array}{c}\text { EP } \\
\text { position }\end{array}$ & $\begin{array}{c}\text { Co- } \\
\text { hesion } \\
\text { index }\end{array}$ \\
\hline $\begin{array}{l}\text { GUE-NGL } \\
\text { (far-left) }\end{array}$ & 0 & 28 & 3 & Against & 85.5 & 0 & 30 & 0 & Against & 100.0 \\
\hline $\begin{array}{l}\text { Greens/EFA } \\
\text { (left/environ- } \\
\text { mentalist) }\end{array}$ & 0 & 51 & 1 & Against & 97.1 & 1 & 52 & 0 & Against & 97.2 \\
\hline $\begin{array}{l}\text { PES } \\
\text { (center-left) }\end{array}$ & 132 & 25 & 0 & For & 76.1 & 119 & 37 & 14 & For & 55.0 \\
\hline $\begin{array}{l}\text { ALDE } \\
\text { (center) }\end{array}$ & 64 & 1 & 1 & For & 95.5 & 75 & 2 & 3 & For & 90.6 \\
\hline $\begin{array}{l}\text { EPP } \\
\text { (center-right) }\end{array}$ & 213 & 0 & 11 & For & 92.6 & 232 & 0 & 9 & For & 94.4 \\
\hline $\begin{array}{l}\text { ECR } \\
\text { (right) }\end{array}$ & 39 & 0 & 0 & For & 100.0 & 46 & 0 & 0 & For & 100.0 \\
\hline $\begin{array}{l}\text { EFD } \\
\text { (right/far- } \\
\text { right) }\end{array}$ & 8 & 10 & 2 & Against & 25.0 & 7 & 11 & 11 & $\begin{array}{c}\text { cular } \\
\text { position }\end{array}$ & 6.9 \\
\hline $\begin{array}{l}\text { NI (non- } \\
\text { inscribed) }\end{array}$ & 9 & 13 & 1 & - & 34.8 & 6 & 15 & 4 & - & 40.0 \\
\hline
\end{tabular}

Note: 1) GUE/NGL: Confederal Group of the European United Left/Nordic Green Left, 2) Greens/ EFA: Group of the Greens/European Free Alliance, 3) PES: Party of European Socialists, 4) ALDE: Alliance of Liberals and Democrats for Europe, 5) EPP: European People's Party, 6) ECR: European Conservatives and Reformists, 7) EFD: Europe of Freedom and Democracy.

Source: VoteWatch.eu 
For the safeguard regulations, we found that MEPs voted with even greater conformity with their European political groups than for the FTAs. The votes incongruent with the parties' dominant positions are very few, in all the political groups. The PES showed very high levels of intra-voting cohesion only with one or two non-conforming votes, while for the FTAs there were a small but non-negligible number of socialist MEPs who rebelled against the discipline of their party. Two possible reasons for this high level of intra-vote cohesion are as follows. First, compared to the FTAs which are not under the direct control of the EP, the safeguard regulations involve MEPs from the phase immediately after the writing of the draft. MEPs can influence the text of the regulation via reports in the assigned committee (INTA in this case) and there is sufficent room for MEPs to influence the regulations in favor of their opinions. Second, given that there are already FTAs on the table, MEPs do not need to think about market access, and focus only on the defensive part of trade legislation. This contributed to reduction of political conflicts in voting, while expanding common interests of MEPs.

Table 4. Votes by political groups in the EP for the safeguard regulations

\begin{tabular}{|c|c|c|c|c|c|c|c|c|c|c|c|c|c|c|c|}
\hline & \multicolumn{5}{|c|}{$\begin{array}{c}\text { Safeguard clause in EU-Korea } \\
\text { FTA }\end{array}$} & \multicolumn{5}{|c|}{$\begin{array}{l}\text { Safeguard clause for bananas } \\
\text { of the EU-Colombia/Peru trade } \\
\text { agreement }\end{array}$} & \multicolumn{5}{|c|}{$\begin{array}{l}\text { Safeguard clause for bananas } \\
\text { of the EU-Central America } \\
\text { association agreement }\end{array}$} \\
\hline & For & Against & \begin{tabular}{|c|} 
Abs- \\
ten- \\
tions
\end{tabular} & \begin{tabular}{c|} 
EP \\
posi- \\
tion
\end{tabular} & $\begin{array}{c}\text { Co- } \\
\text { hesion }\end{array}$ & For & Against & \begin{tabular}{|c|} 
Abs- \\
ten- \\
tions
\end{tabular} & $\begin{array}{c}\text { EP } \\
\text { posi- } \\
\text { tion }\end{array}$ & $\begin{array}{c}\text { Co- } \\
\text { hesion }\end{array}$ & For & Against & $\begin{array}{c}\text { Abs- } \\
\text { ten- } \\
\text { tions }\end{array}$ & \begin{tabular}{c|} 
EP \\
posi- \\
tion
\end{tabular} & $\begin{array}{l}\text { Co- } \\
\text { hesion }\end{array}$ \\
\hline $\begin{array}{l}\text { GUE- } \\
\text { NGL }\end{array}$ & 2 & 2 & 27 & $\begin{array}{c}\text { Abs- } \\
\text { ten- } \\
\text { tions }\end{array}$ & 80.7 & 4 & 26 & 0 & Against & 80.0 & 4 & 26 & 0 & Against & 80.0 \\
\hline $\begin{array}{l}\text { Greens/ } \\
\text { EFA }\end{array}$ & 1 & 3 & 45 & $\begin{array}{c}\text { Abs- } \\
\text { ten- } \\
\text { tions } \\
\end{array}$ & 87.8 & 2 & 6 & 44 & $\begin{array}{l}\text { Abs- } \\
\text { ten- } \\
\text { tions }\end{array}$ & 76.9 & 1 & 6 & 46 & $\begin{array}{l}\text { Abs- } \\
\text { ten- } \\
\text { tions }\end{array}$ & 80.2 \\
\hline PES & 148 & 1 & 1 & For & 98.0 & 170 & 2 & 3 & For & 95.7 & 173 & 0 & 0 & For & 100.0 \\
\hline $\begin{array}{l}\text { ALDE/ } \\
\text { ADLE }\end{array}$ & 66 & 0 & 0 & For & 100.0 & 78 & 1 & 1 & For & 96.3 & 79 & 0 & 1 & For & 98.1 \\
\hline EPP & 212 & 1 & 1 & For & 98.6 & 236 & 0 & 4 & For & 97.5 & 240 & 0 & 3 & For & 98.2 \\
\hline ECR & 36 & 0 & 0 & For & 100.0 & 46 & 0 & 0 & For & 100.0 & 45 & 0 & 1 & For & 96.7 \\
\hline EFD & 18 & 0 & 0 & For & 100.0 & 21 & 1 & 6 & For & 63.8 & 23 & 2 & 5 & For & 65.0 \\
\hline $\mathrm{NI}$ & 12 & 9 & 1 & - & 31.8 & 12 & 11 & 3 & - & 16.0 & 14 & 8 & 3 & - & 34.0 \\
\hline
\end{tabular}

Source: VoteWatch.eu 
In order to have a comparative perspective, we examined intra-voting cohesion according to the nationalities of MEPs, and calculated standard IA from formula used in Hix and Noury (2006). We found that intra-voting cohesions in terms of nationalities are relatively low compared to those in political groups. While some countries recorded a very low level of cohesion, most MEPs from Central and Eastern European countries have a very high rate of cohesion in voting. For example, voting by MEPs from France for the FTAs show perhaps the most divergent pattern, exhibiting a cohesion index of less than 30. This comparison confirms that MEPs vote along with their political groups rather than nationalities.

Table 5. Intra-voting cohesion of MEPs according to nationality in trade legislations

\begin{tabular}{|c|c|c|c|c|c|c|c|}
\hline & $\begin{array}{r}\text { FTA } \\
\text { agre } \\
(t \\
\text { libera }\end{array}$ & $\begin{array}{l}\text { Trade } \\
\text { ments } \\
\text { de } \\
\text { zation) }\end{array}$ & (tra & $\begin{array}{l}\text { Safegua } \\
\text { protecti }\end{array}$ & nism) & $\begin{array}{c}\text { Average } \\
\text { of } 5\end{array}$ & $\begin{array}{l}\text { Average } \\
\text { of all (113) }\end{array}$ \\
\hline & $\begin{array}{l}\text { EU- } \\
\text { Korea }\end{array}$ & $\begin{array}{c}\text { EU- } \\
\text { Colombia }\end{array}$ & $\begin{array}{l}\text { EU- } \\
\text { Korea }\end{array}$ & $\begin{array}{c}\text { EU- } \\
\text { Colombia/ } \\
\text { Peru }\end{array}$ & $\begin{array}{c}\text { EU-Central } \\
\text { America }\end{array}$ & lations & lations \\
\hline France & 27.4 & 27.2 & 55.7 & 51.5 & 54.4 & 43.2 & 66.6 \\
\hline Netherlands & 59.1 & 31.3 & 45.5 & 41.3 & 43.8 & 44.2 & 66.0 \\
\hline Austria & 40.0 & 29.0 & 60.0 & 60.5 & 68.4 & 51.6 & 67.0 \\
\hline Cyprus & 40.0 & 62.5 & 40.0 & 62.5 & 62.5 & 53.5 & 73.3 \\
\hline Latvia & 50.0 & 50.0 & 40.0 & 66.7 & 62.5 & 53.8 & 76.6 \\
\hline Sweden & 62.5 & 36.8 & 62.5 & 52.6 & 60.5 & 55.0 & 73.6 \\
\hline Belgium & 47.1 & 32.5 & 73.5 & 60.5 & 77.5 & 58.2 & 74.8 \\
\hline $\begin{array}{l}\text { United } \\
\text { Kingdom }\end{array}$ & 73.0 & 32.0 & 79.6 & 57.8 & 63.1 & 61.1 & 60.1 \\
\hline Portugal & 64.3 & 52.6 & 70.0 & 60.5 & 60.5 & 61.6 & 72.6 \\
\hline Germany & 63.8 & 55.2 & 66.1 & 66.3 & 66.3 & 63.5 & 77.4 \\
\hline Greece & 60.5 & 55.0 & 75.0 & 71.4 & 72.7 & 66.9 & 76.6 \\
\hline Luxembourg & 70.0 & 75.0 & 70.0 & 75.0 & 70.0 & 72.0 & 83.6 \\
\hline Finland & 75.0 & 62.5 & 72.7 & 75.0 & 76.9 & 72.4 & 78.8 \\
\hline Denmark & 59.1 & 86.4 & 59.1 & 85.0 & 72.7 & 72.5 & 75.2 \\
\hline Estonia & 75.0 & 75.0 & 75.0 & 75.0 & 75.0 & 75.0 & 84.2 \\
\hline Italy & 17.2 & 70.0 & 97.4 & 100.0 & 100.0 & 76.9 & 80.3 \\
\hline $\begin{array}{l}\text { Czech } \\
\text { Republic }\end{array}$ & 60.0 & 72.7 & 70.0 & 100.0 & 100.0 & 80.5 & 75.5 \\
\hline Ireland & 100.0 & 31.8 & 100.0 & 86.4 & 86.4 & 80.9 & 84.6 \\
\hline Hungary & 77.5 & 91.7 & 76.3 & 100.0 & 100.0 & 89.1 & 84.9 \\
\hline Spain & 89.3 & 90.0 & 85.4 & 93.2 & 93.5 & 90.3 & 84.6 \\
\hline
\end{tabular}




\begin{tabular}{|c|c|c|c|c|c|c|c|}
\hline & \multicolumn{2}{|c|}{$\begin{array}{c}\text { FTA/Trade } \\
\text { agreements } \\
\text { (trade } \\
\text { liberalization) }\end{array}$} & \multicolumn{3}{|c|}{$\begin{array}{c}\text { Safeguard } \\
\text { (trade protectionism) }\end{array}$} & \multirow{2}{*}{$\begin{array}{l}\text { Average } \\
\text { of } 5 \\
\text { legis- } \\
\text { lations }\end{array}$} & \multirow{2}{*}{$\begin{array}{c}\text { Average } \\
\text { of all (113) } \\
\text { legis- } \\
\text { lations }\end{array}$} \\
\hline & $\begin{array}{l}\text { EU- } \\
\text { Korea }\end{array}$ & $\begin{array}{c}\text { EU- } \\
\text { Colombia }\end{array}$ & $\begin{array}{l}\text { EU- } \\
\text { Korea }\end{array}$ & $\begin{array}{c}\text { EU- } \\
\text { Colombial } \\
\text { Peru }\end{array}$ & $\begin{array}{c}\text { EU-Central } \\
\text { America }\end{array}$ & & \\
\hline Lithuania & 100.0 & 70.0 & 100.0 & 100.0 & 100.0 & 94.0 & 86.1 \\
\hline Slovenia & 100.0 & 81.3 & 100.0 & 100.0 & 100.0 & 96.3 & 91.0 \\
\hline Bulgaria & 100.0 & 90.6 & 100.0 & 90.6 & 100.0 & 96.3 & 88.2 \\
\hline Slovakia & 100.0 & 87.5 & 100.0 & 100.0 & 100.0 & 97.5 & 88.3 \\
\hline Malta & 100.0 & 100.0 & 100.0 & 100.0 & 100.0 & 100.0 & 91.4 \\
\hline Romania & 100.0 & 100.0 & 100.0 & 100.0 & 100.0 & 100.0 & 91.2 \\
\hline
\end{tabular}

Source: VoteWatch.eu

\subsection{Empirical test of votes: the probit model}

We use a probit model which includes three key variables which capture how MEPs take into consideration their (1) political groups in the EP; (2) national parties; and (3) their electorate in home countries. As mentioned earlier, MEPs voting decisions reflect an interaction of these three factors. In order to measure the level of allegiance to political groups in the EP and national parties, we use two scores provided by VoteWatch - 'Loyalty to political group' (EP affiliation) and 'Loyalty to national party' (NP affiliation), respectively. The scores vary from 0 to 100. A higher score means an MEP tends be loyal to his/her European political groups or national parties. These scores of MEPs are calculated for the period of their mandate up to their voting session for the trade legislation concerned. In order to measure economic conditions of MEPs' electorates, we chose six variables such as change in the trade balance or external export (relative to GDP), as explained in Table 6. The most difficult problem in examining MEPs' individual variables is that MEPs are elected by a proportional represention system and they do not have their districts. For this reason, all variables related to MEPs' electorate are in fact the same as the country variable in the fixed effect model. In order to deal with multicollinearity, we include these variables separately. Our model includes participation rate of roll-call votes in the EP as well. In addition to these three categories of variables, we include the committee assignment of MEPs as a dummy variable. It is expected that MEPs are more concerned about how a particular policy influences the issues that their committee is concerned with. For instance, MEPs of the employment committee are more likely to be concerned regarding any policy measures to increase or maintain employment. 


\subsection{Result}

Table 7 summarizes the analysis on voting patterns of the EP on the EU-Korea FTA. We include country variables one-by-one from (1) to (6). In all cases, 'EP affiliation' has clearly positive coefficients with high levels of statistical significance, while 'National affiliation' has statistically insignificant coefficients. As is already well known, MEPs tend to vote in line with positions of their political groups in the EP. Those MEPs with high allegiance to their EP affiliation vote in favor of the FTA and only a small number of MEPs vote against the discipline of their political groups. This result confirms our previous conclusion from the intra-voting cohesion indexes. As for economic conditions of home countries, half of the variables report statistically significant coefficients. MEPs vote more in favor of the FTA if they are from a country which has a higher unemployment rate and stronger increase in external exports, while MEPs from countries with higher share of external trade are less likely to approve the FTA. This result is hard to interpret; if MEPs take into account how important external trade is for their countries, they are expected to vote in favor of the FTA. Dummy variables of committee assignment all report statistically insignificant coefficients, which is contrary to general expectation. There are some possible reasons. First, most of MEPs are assigned to two or three committees and some MEPs are members of two seemingly conflicting committees, for example INTA and EMPL. This makes it difficult to find diverging interests between the committees. Second, MEPs are less sensitive to pressure from electorates and interest groups, because they do not have particular constituency and they are not supported by financial contributions from any interest groups. This is the most distinguishing feature of MEPs compared to US congressmen.

MEPs' voting for the EU-Korea FTA was largely driven by EP affiliation. National factors both from national parties and economic conditions of home countries did not contribute much to the decision of MEPs. Some rebelling votes of French and Italian MEPs in the PES are exceptional and they do not constitute a general trend. 
Table 6. Variables and data

(Dependent variable: in favor of (1) and against (0) the trade legislation

\begin{tabular}{|c|c|c|c|c|c|c|c|}
\hline \multicolumn{2}{|c|}{ Independent variables } & Contents & Mean & $\begin{array}{l}\text { Std. } \\
\text { Dev. }\end{array}$ & $\begin{array}{l}\text { Mini- } \\
\text { mum }\end{array}$ & $\begin{array}{l}\text { Maxi- } \\
\text { mum }\end{array}$ & Source \\
\hline \multicolumn{2}{|c|}{$\begin{array}{l}\text { EP affiliation: 'Loyalty to political } \\
\text { group' }\end{array}$} & $\begin{array}{l}\text { How much has } \\
\text { an MEP voted } \\
\text { in line with his } \\
\text { EP affiliation? } \\
(0 \sim 100)\end{array}$ & 89.52 & 4.17 & 0.00 & 100.00 & \multirow[b]{2}{*}{ VoteWatch.eu } \\
\hline \multicolumn{2}{|c|}{$\begin{array}{l}\text { National affiliation: 'Loyalty to } \\
\text { national interest' }\end{array}$} & $\begin{array}{l}\text { How much has } \\
\text { an MEP voted } \\
\text { in line with } \\
\text { his national } \\
\text { affiliation? } \\
(0 \sim 100)\end{array}$ & 96.83 & 1.15 & 0.00 & 100.00 & \\
\hline \multirow{7}{*}{$\begin{array}{l}\text { Economic } \\
\text { conditions } \\
\text { of home } \\
\text { countries }\end{array}$} & Unemployment rate & $\%$ & 10.46 & 2.77 & 4.30 & 25.00 & \multirow{7}{*}{ Eurostat } \\
\hline & $\begin{array}{l}\text { Share of external trade } \\
\text { in total trade }\end{array}$ & $\%$ & 36.13 & 2.62 & 15.00 & 59.00 & \\
\hline & External export to GDP & $\%$ & 12.82 & 2.40 & 2.30 & 28.20 & \\
\hline & $\begin{array}{l}\text { Employment share in } \\
\text { manufacture }\end{array}$ & $\%$ & 15.80 & 1.30 & 4.90 & 26.60 & \\
\hline & $\begin{array}{l}\text { Change in trade } \\
\text { balance } \\
(2010-2012, \% \text { of GDP) }\end{array}$ & $\%$ & 0.01 & 0.03 & -0.03 & 0.06 & \\
\hline & $\begin{array}{l}\text { Change in external } \\
\text { export (2009-11 or } \\
2010-2012, \% \text { of GDP) }\end{array}$ & $\%$ & 0.03 & 0.01 & 0.00 & 0.10 & \\
\hline & $\begin{array}{l}\text { Change in import (food } \\
\text { or manufacture) from } \\
\text { FTA partners (2009- } \\
2011 \text { or } 2010-2012, \% \\
\text { of GDP) }\end{array}$ & $\%$ & 0.03 & 0.01 & 0.00 & 0.10 & \\
\hline
\end{tabular}


European Affiliations or National Interests? Analyses of Voting Patterns on Trade Policy in European Parliament

\begin{tabular}{|c|c|c|c|c|c|c|c|}
\hline \multirow{5}{*}{$\begin{array}{l}\text { Commit- } \\
\text { tee } \\
\text { assigned }\end{array}$} & Trade & $\begin{array}{l}\text { If an MEP is } \\
\text { a member } \\
\text { of Trade } \\
\text { Committee, } \\
\text { the value is } 1 \text {, } \\
\text { otherwise } 0 \text {. }\end{array}$ & $\mathrm{N} / \mathrm{A}$ & $\mathrm{N} / \mathrm{A}$ & $\mathrm{N} / \mathrm{A}$ & $\mathrm{N} / \mathrm{A}$ & \multirow{5}{*}{$\begin{array}{l}\text { European } \\
\text { Parliament }\end{array}$} \\
\hline & Industry & $\begin{array}{l}\text { If an MEP is } \\
\text { a member } \\
\text { of Industry } \\
\text { Committee, } \\
\text { the value is } 1 \text {, } \\
\text { otherwise } 0\end{array}$ & $\mathrm{~N} / \mathrm{A}$ & $\mathrm{N} / \mathrm{A}$ & $\mathrm{N} / \mathrm{A}$ & $\mathrm{N} / \mathrm{A}$ & \\
\hline & Environment & $\begin{array}{l}\text { If an MEP is } \\
\text { a member of } \\
\text { Environment } \\
\text { Committee, } \\
\text { the value is } 1 \text {, } \\
\text { otherwise } 0\end{array}$ & $\mathrm{~N} / \mathrm{A}$ & $\mathrm{N} / \mathrm{A}$ & $\mathrm{N} / \mathrm{A}$ & $\mathrm{N} / \mathrm{A}$ & \\
\hline & Employment & $\begin{array}{l}\text { If an MEP is } \\
\text { a member of } \\
\text { Employment } \\
\text { Committee, } \\
\text { the value is } 1 \text {, } \\
\text { otherwise } 0\end{array}$ & $\mathrm{~N} / \mathrm{A}$ & $\mathrm{N} / \mathrm{A}$ & $\mathrm{N} / \mathrm{A}$ & $\mathrm{N} / \mathrm{A}$ & \\
\hline & Agriculture & $\begin{array}{l}\text { If an MEP is } \\
\text { a member of } \\
\text { Agriculture } \\
\text { Committee, } \\
\text { the value is } 1 \text {, } \\
\text { otherwise } 0\end{array}$ & $\mathrm{~N} / \mathrm{A}$ & $\mathrm{N} / \mathrm{A}$ & $\mathrm{N} / \mathrm{A}$ & $\mathrm{N} / \mathrm{A}$ & \\
\hline \multicolumn{2}{|c|}{ Participation rate } & $\begin{array}{l}\text { Participation } \\
\text { rate }(0 \sim 100, \\
\%) \text { in roll-call } \\
\text { votes }\end{array}$ & 84.74 & 1.27 & 0 & 99.6 & VoteWatch.eu \\
\hline
\end{tabular}


Table 7. Result of estimating voting equation

(Consent on EU-Korea FTA by the EP)

\begin{tabular}{|c|c|c|c|c|c|c|c|}
\hline & & (1) & (2) & (3) & (4) & (5) & (6) \\
\hline Constant & & $\begin{array}{l}-2.4566^{* * *} \\
(0.818)\end{array}$ & $\begin{array}{l}-0.876 \\
(0.856)\end{array}$ & $\begin{array}{l}-2.008^{* *} \\
(0.796)\end{array}$ & $\begin{array}{l}-2.135^{\text {t*t }} \\
(0.798)\end{array}$ & $\begin{array}{l}-1.934^{* *} \\
(0.786)\end{array}$ & $\begin{array}{l}-2.054^{*+1+x} \\
(0.788)\end{array}$ \\
\hline EP affiliatio & & $\begin{array}{l}0.010^{*+*} \\
(0.003)\end{array}$ & $\begin{array}{l}0.011^{*+* t} \\
(0.003)\end{array}$ & $\begin{array}{l}0.010^{*+*} \\
(0.003)\end{array}$ & $\begin{array}{l}0.010^{*+*} \\
(0.003)\end{array}$ & $\begin{array}{l}0.011^{\prime+* *+} \\
(0.003)\end{array}$ & $\begin{array}{l}0.010^{*+*} \\
(0.003)\end{array}$ \\
\hline NP affiliatio & & $\begin{array}{c}0.006 \\
(0.005)\end{array}$ & $\begin{array}{c}0.004 \\
(0.005)\end{array}$ & $\begin{array}{c}0.005 \\
(0.005)\end{array}$ & $\begin{array}{c}0.005 \\
(0.005)\end{array}$ & $\begin{array}{c}0.005 \\
(0.005)\end{array}$ & $\begin{array}{c}0.005 \\
(0.005)\end{array}$ \\
\hline & $\begin{array}{l}\text { Unemployment } \\
\text { rate }\end{array}$ & $\begin{array}{l}0.032^{* *} \\
(0.013)\end{array}$ & & & & & \\
\hline & $\begin{array}{l}\text { Share of external } \\
\text { trade in total } \\
\text { trade }\end{array}$ & & $\begin{array}{c}-0.022^{* * *} \\
(0.007)\end{array}$ & & & & \\
\hline & $\begin{array}{l}\text { External export } \\
\text { to GDP }\end{array}$ & & & $\begin{array}{c}0.008 \\
(0.012)\end{array}$ & & & \\
\hline $\begin{array}{l}\text { Economic } \\
\text { conditions } \\
\text { of home }\end{array}$ & $\begin{array}{l}\text { Employment } \\
\text { share in } \\
\text { manufacture }\end{array}$ & & & & $\begin{array}{c}0.023 \\
(0.014)\end{array}$ & & \\
\hline countries & $\begin{array}{l}\text { Change in trade } \\
\text { balance } \\
(2010-2012, \% \text { of } \\
\text { GDP) } \\
\end{array}$ & & & & & $\begin{array}{l}-5.617 \\
(4.514)\end{array}$ & \\
\hline & $\begin{array}{l}\text { Change in } \\
\text { external export } \\
(2010-2012, \% \text { of } \\
\text { GDP) }\end{array}$ & & & & & & $\begin{array}{c}6.788^{*} \\
(4.094)\end{array}$ \\
\hline & Trade & $\begin{array}{l}-0.195 \\
(0.238)\end{array}$ & $\begin{array}{l}-0.180 \\
(0.239)\end{array}$ & $\begin{array}{l}-0.196 \\
(0.237)\end{array}$ & $\begin{array}{l}-0.215 \\
(0.236)\end{array}$ & $\begin{array}{l}-0.206 \\
(0.237)\end{array}$ & $\begin{array}{l}-0.202 \\
(0.238)\end{array}$ \\
\hline & Industry & $\begin{array}{c}0.019 \\
(0.174)\end{array}$ & $\begin{array}{l}-0.008 \\
(0.175) \\
\end{array}$ & $\begin{array}{c}0.017 \\
(0.173)\end{array}$ & $\begin{array}{c}0.025 \\
(0.173) \\
\end{array}$ & $\begin{array}{c}0.007 \\
(0.173) \\
\end{array}$ & $\begin{array}{c}0.017 \\
(0.174) \\
\end{array}$ \\
\hline $\begin{array}{l}\text { Commit- } \\
\text { tee }\end{array}$ & Environment & $\begin{array}{l}-0.004 \\
(0.174) \\
\end{array}$ & $\begin{array}{c}0.006 \\
(0.174) \\
\end{array}$ & $\begin{array}{l}-0.018 \\
(0.172) \\
\end{array}$ & $\begin{array}{l}-0.005 \\
(0.173) \\
\end{array}$ & $\begin{array}{l}-0.031 \\
(0.173) \\
\end{array}$ & $\begin{array}{l}-0.004 \\
(0.173) \\
\end{array}$ \\
\hline & Employment & $\begin{array}{l}-0.275 \\
(0.184)\end{array}$ & $\begin{array}{l}-0.275 \\
(0.186)\end{array}$ & $\begin{array}{l}-0.269 \\
(0.183)\end{array}$ & $\begin{array}{l}-0.266 \\
(0.184)\end{array}$ & $\begin{array}{l}-0.261 \\
(0.183)\end{array}$ & $\begin{array}{l}-0.277 \\
(0.184)\end{array}$ \\
\hline & Agriculture & $\begin{array}{c}0.226 \\
(0.212) \\
\end{array}$ & $\begin{array}{c}0.278 \\
(0.212) \\
\end{array}$ & $\begin{array}{c}0.249 \\
(0.209) \\
\end{array}$ & $\begin{array}{c}0.270 \\
(0.210)\end{array}$ & $\begin{array}{c}0.235 \\
(0.210) \\
\end{array}$ & $\begin{array}{c}0.252 \\
(0.209) \\
\end{array}$ \\
\hline Participatio & $\mathrm{n}$ rate & $\begin{array}{l}0.018^{* *} \\
(0.008)\end{array}$ & $\begin{array}{l}0.013^{*} \\
(0.008)\end{array}$ & $\begin{array}{l}0.015^{* *} \\
(0.008)\end{array}$ & $\begin{array}{l}0.015^{*} \\
(0.008)\end{array}$ & $\begin{array}{l}0.016^{* *} \\
(0.008)\end{array}$ & $\begin{array}{l}0.015^{*} \\
(0.008)\end{array}$ \\
\hline Total Obser & vations & 544 & 544 & 544 & 544 & 544 & 544 \\
\hline McFadden & & 0.06 & 0.07 & 0.05 & 0.06 & 0.05 & 0.06 \\
\hline Log likeliho & & -257.94 & -256.21 & -260.96 & -259.94 & -260.41 & -259.75 \\
\hline
\end{tabular}

Free trade agreement between the EU and the Republic on Korea - Draft legislative resolution-

Recommendation: vote: legislative resolution - consent

Note: Standard errors are given in parentheses. ${ }^{* * *},{ }^{* *}$ and ${ }^{*}$ indicate statistical signifi-

cance level at $1 \%, 5 \%$ and $10 \%$, respectively. 
In the case of voting on EU-Colombia/Peru Trade Agreement, the result shows a similar trend strongly inclined toward EP affiliation in the voting decision. In all cases from (1) to (6), MEPs with higher 'EP affiliation' tend to vote in favor of the agreement and in some cases, the level of national affiliations have explanatory power for MEPs' voting decisions. Compared to the voting on the EU-Korea FTA, country-specific variables have statistically significant coefficients. Most of the variables are clearly positive coefficients with good levels of statistical significance except the level of the external exports to GDP. If country-specific situations are fully reflected on MEPs' voting decisions, MEPs are more likely to vote for the agreement, if they are from countries which have been experiencing increasing export and share of employment in manufacture. However, given coherent and high coefficients of EP affiliation, it is difficult to conclude that country-specific factors override European party discipline.

Table 8. Result of estimating voting equation (Consent on EU-Colombia/Peru Trade Agreement by the EP)

\begin{tabular}{|c|c|c|c|c|c|c|c|}
\hline & & (1) & (2) & (3) & (4) & (5) & (6) \\
\hline Constant & & $\begin{array}{l}-2.319^{*+*} \\
(0.800)\end{array}$ & $\begin{array}{l}-0.285 \\
(0.836)\end{array}$ & $\begin{array}{l}-1.595 \\
(0.771)\end{array}$ & $\begin{array}{l}-2.226^{*+*} \\
(0.785)\end{array}$ & $\begin{array}{l}-1.688^{* *} \\
(0.773)\end{array}$ & $\begin{array}{l}-1.770 \\
(0.776)\end{array}$ \\
\hline EP affiliatic & & $\begin{array}{l}0.017^{4 * *} \\
(0.003)\end{array}$ & $\begin{array}{l}0.018^{\prime+1} \\
(0.003)\end{array}$ & $\begin{array}{l}0.018^{*+1} \\
(0.003)\end{array}$ & $\begin{array}{l}0.016 \\
(0.003)\end{array}$ & $\begin{array}{l}0.016 \\
(0.003)\end{array}$ & $\begin{array}{l}0.017^{7+1} \\
(0.003)\end{array}$ \\
\hline NP affiliatic & & $\begin{array}{l}0.010^{* *} \\
(0.005)\end{array}$ & $\begin{array}{c}0.009 \\
(0.005)\end{array}$ & $\begin{array}{c}0.010 \\
(0.005)\end{array}$ & $\begin{array}{c}0.010 \\
(0.005)\end{array}$ & $\begin{array}{l}0.010^{* *} \\
(0.005)\end{array}$ & $\begin{array}{l}0.009^{*} \\
(0.005)\end{array}$ \\
\hline & $\begin{array}{l}\text { Unemployment } \\
\text { rate }\end{array}$ & $\begin{array}{l}0.039^{+* *+} \\
(0.012)\end{array}$ & & & & & \\
\hline & $\begin{array}{l}\text { Share of external } \\
\text { trade in total trade }\end{array}$ & & $\begin{array}{c}-0.028{ }^{*} \\
(0.006)\end{array}$ & & & & \\
\hline & $\begin{array}{l}\text { External export to } \\
\text { GDP }\end{array}$ & & & $\begin{array}{l}-0.012 \\
(0.011)\end{array}$ & & & \\
\hline conditions & $\begin{array}{l}\text { Employment share } \\
\text { in manufacture }\end{array}$ & & & & $\begin{array}{l}0.059^{* *+} \\
(0.013)\end{array}$ & & \\
\hline countries & $\begin{array}{l}\text { Change in trade } \\
\text { balance } \\
(2010-2012, \% \text { of } \\
\text { GDP) }\end{array}$ & & & & & $\begin{array}{l}10.200^{*+*} \\
(4.067)\end{array}$ & \\
\hline & $\begin{array}{l}\text { Change in external } \\
\text { export } \\
\text { (2010-2012, \% of } \\
\text { GDP) }\end{array}$ & & & & & & $\begin{array}{l}8.893^{* \prime} \\
(3.765)\end{array}$ \\
\hline
\end{tabular}




\begin{tabular}{|c|c|c|c|c|c|c|c|}
\hline & & (1) & (2) & (3) & (4) & (5) & (6) \\
\hline \multirow{5}{*}{$\begin{array}{l}\text { Commit- } \\
\text { tee }\end{array}$} & Trade & $\begin{array}{c}-0.002 \\
(0.207)\end{array}$ & $\begin{array}{l}-0.007 \\
(0.208)\end{array}$ & $\begin{array}{l}-0.021 \\
(0.205)\end{array}$ & $\begin{array}{l}-0.025 \\
(0.209)\end{array}$ & $\begin{array}{c}0.002 \\
(0.206)\end{array}$ & $\begin{array}{c}0.009 \\
(0.206)\end{array}$ \\
\hline & Industry & $\begin{array}{c}0.113 \\
(0.167) \\
\end{array}$ & $\begin{array}{c}0.074 \\
(0.167)\end{array}$ & $\begin{array}{c}0.119 \\
(0.166)\end{array}$ & $\begin{array}{c}0.119 \\
(0.167)\end{array}$ & $\begin{array}{c}0.120 \\
(0.166) \\
\end{array}$ & $\begin{array}{c}0.114 \\
(0.166) \\
\end{array}$ \\
\hline & Environment & $\begin{array}{l}-0.140 \\
(0.154) \\
\end{array}$ & $\begin{array}{l}-0.139 \\
(0.155)\end{array}$ & $\begin{array}{l}-0.148 \\
(0.153)\end{array}$ & $\begin{array}{l}-0.146 \\
(0.155)\end{array}$ & $\begin{array}{c}-0.146 \\
(0.153) \\
\end{array}$ & $\begin{array}{c}-0.156 \\
(0.153) \\
\end{array}$ \\
\hline & Employment & $\begin{array}{l}-0.275^{*} \\
(0.168)\end{array}$ & $\begin{array}{l}-0.263 \\
(0.171)\end{array}$ & $\begin{array}{l}-0.250 \\
(0.168)\end{array}$ & $\begin{array}{l}-0.283 \\
(0.171)\end{array}$ & $\begin{array}{c}-0.275 \\
(0.169) \\
\end{array}$ & $\begin{array}{c}-0.262^{*} \\
(0.169) \\
\end{array}$ \\
\hline & Agriculture & $\begin{array}{c}0.178 \\
(0.194) \\
\end{array}$ & $\begin{array}{c}0.250 \\
(0.194)\end{array}$ & $\begin{array}{c}0.202 \\
(0.192)\end{array}$ & $\begin{array}{c}0.251 \\
(0.194)\end{array}$ & $\begin{array}{c}0.219 \\
(0.192) \\
\end{array}$ & $\begin{array}{c}0.242 \\
(0.191)\end{array}$ \\
\hline \multicolumn{2}{|c|}{ Total Observations } & 621 & 621 & 621 & 621 & 621 & 621 \\
\hline \multicolumn{2}{|c|}{ McFadden $R^{2}$} & 0.08 & 0.09 & 0.07 & 0.10 & 0.07 & 0.07 \\
\hline \multicolumn{2}{|c|}{ Log likelihood } & -309.79 & -305.57 & -314.86 & -304.55 & -312.28 & -312.48 \\
\hline
\end{tabular}

EU-Colombia/Peru trade agreement - Draft legislative resolution: vote: approbation - consent Note: Standard errors are given in parentheses. ${ }^{* * *},{ }^{* *}$ and ${ }^{*}$ indicate statistical significance level at $1 \%, 5 \%$ and $10 \%$, respectively.

We examined the voting patterns of the EP on three safeguard legislations. The results are summarized in Tables 9, 10, and 11. For the safeguard clause in the EU-Korea FTA, 'EP affiliation' has a highly positive and statistically significant coefficients over all cases, while 'National affiliation' reports insignificant coefficients. Most of the country-specific variables under consideration do not appear statistically significant except the share of employment in manufacture, which is positively correlated with the approval of the safeguard legislation. The variables of the committee assignment do not report statistically significant coefficients.

For the safeguard for bananas from Central America and Colombia/Peru, the results are not much different from the safeguard clause under the EU-Korea FTA. 'EP affiliation' has highly significant coefficients over all cases and the level of the national affiliations does not appear correlated with the voting decision of MEPs. Most country-specific variables do not have statistically significant coefficients. 
Table 9. Result of estimating voting equation

(OLP on bilateral safeguard clause in the EU-Korea FTA)

\begin{tabular}{|c|c|c|c|c|c|c|c|}
\hline & (1) & (2) & (3) & (4) & (5) & (6) \\
\hline \multicolumn{2}{|l|}{ Constant } & $\begin{array}{l}-2.238 \\
(1.609)\end{array}$ & $\begin{array}{l}-2.212 \\
(1.748)\end{array}$ & $\begin{array}{l}-3.121^{*} \\
(1.731)\end{array}$ & $\begin{array}{l}-3.152^{*} \\
(1.683)\end{array}$ & $\begin{array}{l}-2.495 \\
(1.578)\end{array}$ & $\begin{array}{l}-2.149 \\
(1.581)\end{array}$ \\
\hline \multicolumn{2}{|c|}{ EP affiliation } & $\begin{array}{l}0.018^{+1+*} \\
(0.004)\end{array}$ & $\begin{array}{l}0.018^{+* *+} \\
(0.004)\end{array}$ & $\begin{array}{l}0.019^{*+*} \\
(0.004)\end{array}$ & $\begin{array}{l}0.018^{+*+1} \\
(0.004)\end{array}$ & $\begin{array}{l}0.018^{+*+1} \\
(0.004)\end{array}$ & $\begin{array}{l}0.018^{\prime+*} \\
(0.004)\end{array}$ \\
\hline \multicolumn{2}{|c|}{ NP affiliation } & $\begin{array}{c}0.004 \\
(0.011)\end{array}$ & $\begin{array}{c}0.004 \\
(0.011)\end{array}$ & $\begin{array}{c}0.004 \\
(0.012)\end{array}$ & $\begin{array}{c}0.003 \\
(0.011)\end{array}$ & $\begin{array}{c}0.005 \\
(0.011)\end{array}$ & $\begin{array}{c}0.003 \\
(0.011)\end{array}$ \\
\hline \multirow{6}{*}{$\begin{array}{l}\text { Economic } \\
\text { conditions } \\
\text { of home } \\
\text { countries }\end{array}$} & Unemployment rate & $\begin{array}{l}-0.003 \\
(0.026)\end{array}$ & & & & & \\
\hline & $\begin{array}{l}\text { Share of external } \\
\text { trade in total trade }\end{array}$ & & $\begin{array}{l}-0.001 \\
(0.015)\end{array}$ & & & & \\
\hline & $\begin{array}{l}\text { External export to } \\
\text { GDP }\end{array}$ & & & $\begin{array}{c}0.053 \\
(0.035)\end{array}$ & & & \\
\hline & $\begin{array}{l}\text { Employment share } \\
\text { in manufacture }\end{array}$ & & & & $\begin{array}{l}0.067^{*} \\
(0.037)\end{array}$ & & \\
\hline & \begin{tabular}{|l|} 
Change in trade \\
balance \\
$(2010-2012, \%$ of \\
GDP) \\
\end{tabular} & & & & & $\begin{array}{c}14.865 \\
(10.610)\end{array}$ & \\
\hline & $\begin{array}{l}\text { Change in import } \\
\text { from Korea } \\
(2009-2011, \% \text { of } \\
\text { GDP) }\end{array}$ & & & & & & $\begin{array}{c}0.513 \\
(0.725)\end{array}$ \\
\hline \multirow{3}{*}{ Committee } & Trade & $\begin{array}{l}-0.459 \\
(0.389)\end{array}$ & $\begin{array}{l}-0.457 \\
(0.389)\end{array}$ & $\begin{array}{l}-0.464 \\
(0.405)\end{array}$ & $\begin{array}{l}-0.385 \\
(0.420)\end{array}$ & $\begin{array}{l}-0.385 \\
(0.420)\end{array}$ & $\begin{array}{l}-0.479 \\
(0.392)\end{array}$ \\
\hline & Industry & $\begin{array}{c}0.266 \\
(0.414)\end{array}$ & $\begin{array}{c}0.263 \\
(0.412)\end{array}$ & $\begin{array}{c}0.286 \\
(0.419)\end{array}$ & $\begin{array}{c}0.311 \\
(0.437)\end{array}$ & $\begin{array}{c}0.311 \\
(0.437)\end{array}$ & $\begin{array}{c}0.262 \\
(0.417)\end{array}$ \\
\hline & Employment & $\begin{array}{l}-0.114 \\
(0.397)\end{array}$ & $\begin{array}{l}-0.110 \\
(0.396)\end{array}$ & $\begin{array}{l}-0.087 \\
(0.418)\end{array}$ & $\begin{array}{l}-0.004 \\
(0.431)\end{array}$ & $\begin{array}{l}-0.004 \\
(0.431)\end{array}$ & $\begin{array}{l}-0.124 \\
(0.398)\end{array}$ \\
\hline \multicolumn{2}{|c|}{ Participation rate } & $\begin{array}{c}0.028 \\
(0.014)\end{array}$ & $\begin{array}{l}0.028 * \\
(0.014)\end{array}$ & $\begin{array}{l}0.030 * \\
(0.014)\end{array}$ & $\begin{array}{l}0.028^{* *} \\
(0.014)\end{array}$ & $\begin{array}{l}0.030 * \\
(0.014)\end{array}$ & $\begin{array}{l}0.027^{*} \\
(0.014)\end{array}$ \\
\hline \multicolumn{2}{|c|}{ Total Observations } & 464 & 464 & 464 & 464 & 464 & 464 \\
\hline \multicolumn{2}{|c|}{ McFadden $R^{2}$} & 0.27 & 0.27 & 0.29 & 0.32 & 0.28 & 0.30 \\
\hline \multicolumn{2}{|c|}{ Log likelihood } & -46.02 & -46.02 & -44.61 & -42.84 & -45.04 & -44.23 \\
\hline
\end{tabular}

Bilateral safeguard clause in the EU-Korea free trade agreement - Draft legislative resolution-

Ordinary legislative procedure: first reading: vote: legislative resolution - ordinary legislative procedure, first reading

Note: Standard errors are given in parentheses. ${ }^{* * *},{ }^{* *}$ and ${ }^{*}$ indicate statistical significance level at $1 \%, 5 \%$ and $10 \%$, respectively. 
Table 10. Result of estimating voting equation (OLP on the bilateral safeguard clause for bananas of the EC-Central America Association agreement)

\begin{tabular}{|c|c|c|c|c|c|c|c|}
\hline \multicolumn{3}{|r|}{ (1) } & $(2)$ & (3) & (4) & (5) & $(6)$ \\
\hline \multicolumn{2}{|l|}{ Constant } & $\begin{array}{c}0.211 \\
(2.049\end{array}$ & $\begin{array}{c}1.450 \\
(1.895)\end{array}$ & $\begin{array}{c}0.291 \\
(1.890)\end{array}$ & $\begin{array}{l}-0.278 \\
(1.613)\end{array}$ & $\begin{array}{c}0.367 \\
(1.786)\end{array}$ & $\begin{array}{c}0.320 \\
(1.959)\end{array}$ \\
\hline \multicolumn{2}{|c|}{ EP affiliation } & $\begin{array}{l}0.015^{* * *} \\
(0.003\end{array}$ & $\begin{array}{l}0.015^{* * *} \\
(0.003)\end{array}$ & $\begin{array}{l}0.016 \\
(0.003)\end{array}$ & $\begin{array}{l}0.014^{* * *+} \\
(0.003)\end{array}$ & $\begin{array}{l}0.015^{* * *} \\
(0.003)\end{array}$ & $\begin{array}{l}0.016^{* *+4} \\
(0.003)\end{array}$ \\
\hline \multicolumn{2}{|c|}{ NP affiliation } & $\begin{array}{l}-0.009 \\
(0.020\end{array}$ & $\begin{array}{l}-0.009 \\
(0.018)\end{array}$ & $\begin{array}{l}-0.009 \\
(0.018)\end{array}$ & $\begin{array}{l}-0.006 \\
(0.015)\end{array}$ & $\begin{array}{l}-0.007 \\
(0.017)\end{array}$ & $\begin{array}{l}-0.010 \\
(0.019)\end{array}$ \\
\hline \multirow{6}{*}{$\begin{array}{l}\text { Economic } \\
\text { conditions } \\
\text { of home } \\
\text { countries }\end{array}$} & $\begin{array}{l}\text { Unemployment } \\
\text { rate }\end{array}$ & $\begin{array}{l}0.020 \\
(0.019\end{array}$ & & & & & \\
\hline & $\begin{array}{l}\text { Share of external } \\
\text { trade in total trade }\end{array}$ & & $\begin{array}{l}-0.021^{* *} \\
(0.009)\end{array}$ & & & & \\
\hline & $\begin{array}{l}\text { External export to } \\
\text { GDP }\end{array}$ & & & $\begin{array}{c}0.020 \\
(0.015)\end{array}$ & & & \\
\hline & $\begin{array}{l}\text { Employment share } \\
\text { in manufacture }\end{array}$ & & & & $\begin{array}{l}0.047^{* *} \\
(0.020)\end{array}$ & & \\
\hline & $\begin{array}{l}\text { Change in trade } \\
\text { balance } \\
\text { (2010-2012, \% of } \\
\text { GDP) }\end{array}$ & & & & & $\begin{array}{l}3.144 \\
(5.570)\end{array}$ & \\
\hline & $\begin{array}{l}\text { Change in food } \\
\text { import from Central } \\
\text { America } \\
(2010-2012, \% \text { of } \\
\text { GDP) }\end{array}$ & & & & & & $\begin{array}{l}13.564^{* *} \\
(6.323)\end{array}$ \\
\hline \multicolumn{2}{|c|}{ Participation rate } & $\begin{array}{l}0.008 \\
(0.008\end{array}$ & $\begin{array}{c}0.005 \\
(0.008)\end{array}$ & $\begin{array}{c}0.005 \\
(0.008)\end{array}$ & $\begin{array}{c}0.005 \\
(0.008)\end{array}$ & $\begin{array}{c}0.007 \\
(0.008)\end{array}$ & $\begin{array}{c}0.005 \\
(0.008)\end{array}$ \\
\hline \multicolumn{2}{|c|}{ Total Observations } & 603 & 603 & 603 & 603 & 603 & 603 \\
\hline \multicolumn{2}{|c|}{ McFadden $R^{2}$} & 0.10 & 0.11 & 0.10 & 0.11 & 0.09 & 0.11 \\
\hline \multicolumn{2}{|c|}{ Log likelihood } & -135.55 & -133.41 & -135.32 & -133.43 & -136.03 & -133.32 \\
\hline
\end{tabular}

Implementation of the bilateral safeguard clause and the stabilization mechanism for bananas of the EU-Central America association agreement - Draft legislative resolution: vote: resolution (as a whole) - ordinary legislative procedure, first reading

Note: Standard errors are given in parentheses. ${ }^{* * *},{ }^{* *}$ and ${ }^{*}$ indicate statistical significance level at $1 \%, 5 \%$ and $10 \%$, respectively. 
Table 11. Result of calculation by voting equation (OLP on the bilateral safeguard clause for bananas of the EU-Colombia/Peru Trade Agreement)

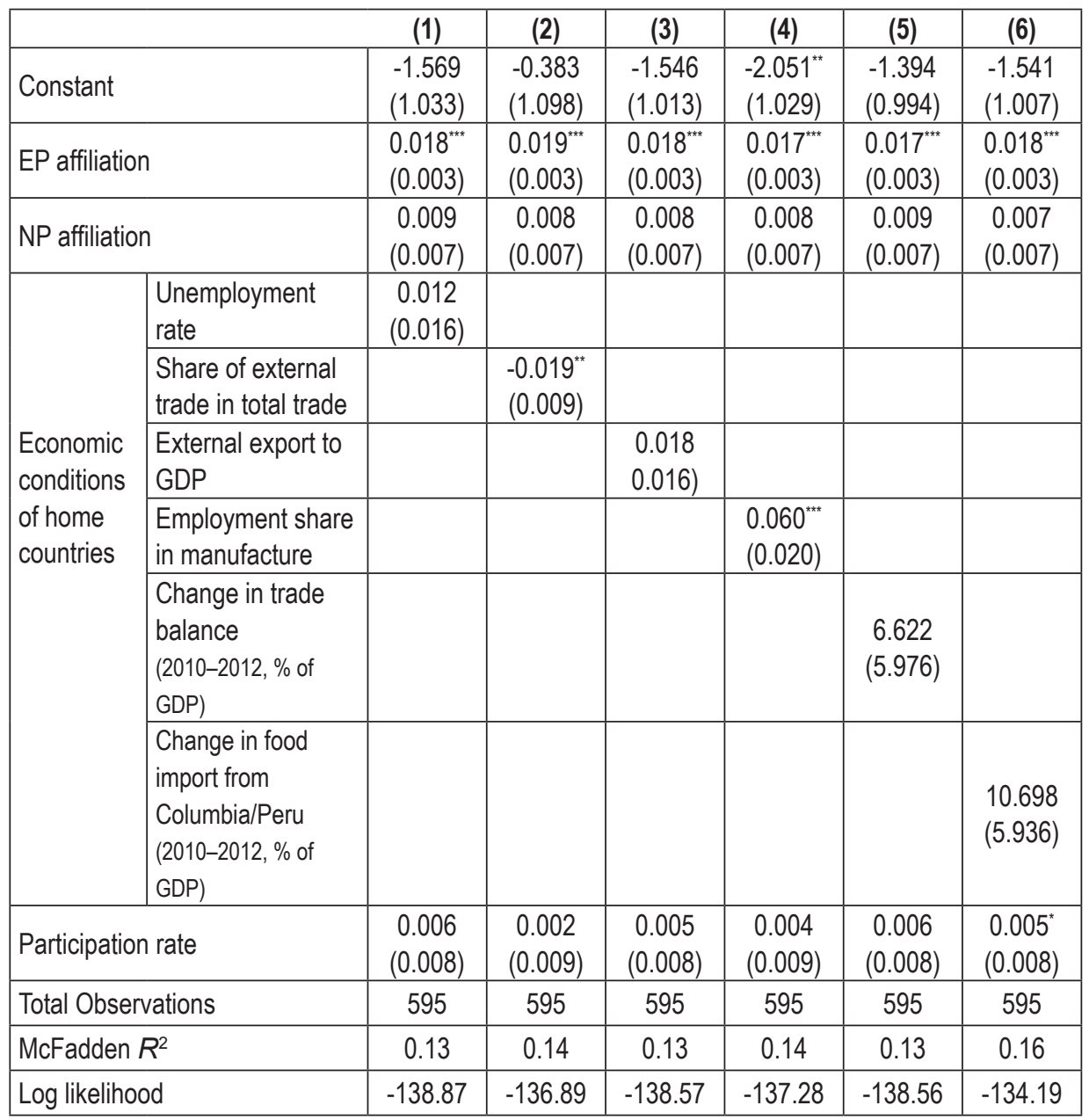

Implementation of the bilateral safeguard clause and the stabilization mechanism for bananas of the EU-Colombia/Peru trade agreement - Draft legislative resolution: vote: legislative resolution - ordinary legislative procedure, first reading

Note: Standard errors are given in parentheses. ${ }^{* * *},{ }^{* *}$ and ${ }^{*}$ indicate statistical significance level at $1 \%, 5 \%$ and $10 \%$, respectively. 


\section{Concluding remarks}

Most of the previous studies on the voting behavior of the EP focus on checking the intra-voting pattern of MEPs. They concluded that MEPs tend to vote along with their European party affiliations. We tried to revisit this trend in trade legislations and examined the voting pattern over three factors: European affiliation, national affiliation, and the economic situation of home countries.

We found that the MEPs still tend to vote with others in their political groups in trade legislations and their voting pattern is not very different from the previous pattern. This trend is confirmed by both the comparison of intra-voting cohesion index and the empirical test based on the probit model. Country-specific variables do not explain well the voting behavior of MEPs. Even though these variables have statistically significant coefficients, it is hard to find clear and coherent logic to explain the channels of influence from these economic conditions of home countries to voting decisions of the MEPs. However, when we review the data of individual MEPs, some MEPs of the PES cast their ballots against the dominant position. These minority votes did not overturn the general trend, but it is noteworthy that some MEPs voted in line with their national interests on certain sensitive issues. If we focus on the cases of EP's vote in which European political groups and national parties have opposing views, it is likely that the cohesion of the EP parties declines.

It is expected that the influence of the EP on EU trade policy would increase over time, as MEPs realize their new powers and learn how to use it to reflect their opinion on EU trade agenda. This might complicate the policy-making process with greater politicization of trade issues. As the EU expands its FTAs to more trade partners, more active involvements from the EP are expected. This means that various interest groups, such as trade associations and NGOs will attempt to exert greater influence on the European Parliament as well as the European Commission.

Yoo-Duk Kang is a professor of economics at the Hankuk University of Foreign Studies and he teaches international economics and trade. His main research interest is trade policy and economic integration. He received an $\mathrm{MA}$ and $\mathrm{PhD}$ in Economics from the Institut d'Etudes Politiques de Paris (Sciences Po). 


\section{References}

ACEA (2009), 'European automobile industry requests EU to suspend trade negotiations with South Korea,' ACEA Press Release, 5 February.

Attinà, F. (1990), 'The voting behaviour of the European Parliament members and the problem of Europarties,' European Journal of Political Research, no. 18. pp. 557-579. https://doi.org/10.1111/j.1475-6765.1990.tb00248.x

Baldwin, R. E. \& Magee, C. S. (2000), Congressional Trade Votes: From NAFTA Approval to Fast-Track Defeat, Policy Analyses in International Economics no. 59, Washington, DC: Institute for International Economics.

Brzinski, J. B. (1995), 'Political group cohesion in the European Parliament, 19891994,' in C. Rhodes \& S. Mazey (eds.) The State of the European Union, vol. 3, London: Longman.

European Commission (2006), Global Europe: Competing in the World, COM(2006) 567 final, 4.10.2006.

European Parliament (2013), The European Parliament: Electoral Procedures, Fact Sheets on the European Union - 2013, Brussels: European Parliament.

Héritier, A.; Moury, C.; Schoeller, M.; Meissner, K. \& Mota, I. (2015), The European Parliament as a Driving Force of Constitutionalisation, Brussels: European Parliament.

Hiscox, M. J. (2002), 'Commerce, coalition, and factor mobility: evidence from congressional votes on trade legislation,' The American Political Science Review, vol. 96, no. 3, pp. 593-608. https://doi.org/10.1017/S0003055402000357

Hix, S. (2000), How MEPs Vote, ESRC One Europe or Several? Programme Briefing Note 1/00, Falmer: University of Sussex.

Hix, S. (2001), 'Legislative behaviour and party competition in the European Parliament: an application of nominate to the EU,' Journal of Common Market Studies, vol. 39, no. 4, pp. 663-688. https://doi.org/10.1111/1468-5965.00326

Hix, S. (2002), 'Parliamentary behavior with two principals: preferences, parties and voting in the European Parliament,' American Journal of Political Science, vol. 46, no. 3, pp. 688-698. https://doi.org/10.2307/3088408

Hix, S. \& Høyland, B. (2013), 'Empowerment of the European Parliament,' Annual Review of Political Science, vol. 16, pp. 171-189. https://doi.org/10.1146/annurevpolisci-032311-110735

Hix, S. \& Lord, C. (1997), Political Parties in the European Union, London: Macmillan. https://doi.org/10.1007/978-1-349-25560-3

Hix, S. \& Noury, A. (2009a), 'After enlargement: voting patterns in the Sixth European Parliament,' Legislative Studies Quarterly, vol. 34, no. 2, pp. 159-174.

https://doi.org/10.3162/036298009788314282 
Hix, S. \& Noury, A. (2009b), 'Voting patterns and alliance formation in the European Parliament,' Philosophical Transactions of the Royal Society, no. 364, pp. 821-831. https://doi.org/10.1098/rstb.2008.0263

Hix, S.; Noury, A. \& Roland, G. (2007), Democratic Politics in the European Parliament, Cambridge, MA: Cambridge University Press. https://doi.org/10.1017/CBO9780511491955

Krajewski, M. (2005), 'External trade law and the Constitution Treaty: towards a federal and more democratic common commercial policy?' Common Market Law Review, no. 1, pp. 91-127.

Lim, H. \& Sung, H. (2011), 'Empirical analyses of U.S. congressional voting on recent FTA,' The B. E. Journal of Economic Analysis and Policy, vol. 11, no. 1, pp. 1-37. https://doi.org/10.2202/1935-1682.2363

Noury, A. G. \& Roland, G. (2002), 'European Parliament: Should it have more power?' Economy Policy, vol. 17, no. 35, pp. 279-319.

Van den Putte, L.; De Ville, F. \& Orbie, J. (2014), The European Parliament's New Role in Trade Policy: Turning Power into Impact, CEPS Special Report, no. 89. Retrieved from http://aei.pitt.edu/51025/1/CEPS_SR_89_EP_New_Role_in_EU_ Trade_Policy.pdf [accessed Sep 2019]

Raunio, T. (1997), The European Perspective: Transnational Party Groups in the 1989-1994 European Parliament, London: Ashgate.

Reichert, T. (2004), 'EU trade policy decision making and WWF's trade policy work in Brussels,' Paper presented at seminar 'The Relationship between MEAs and WTO Rules', Szentendre (10 May 2004).

Ringe, N. (2010), Who Decides, and How? Preferences, Uncertainty, and Policy Choice in the European Parliament, Oxford: Oxford University Press. https://doi.org/10.1093/acprof:oso/9780199572557.003.0001

VoteWatch (2010), Voting Behaviour in the New European Parliament: The First Year, Annual Report 2010.

Wolfstädter, L.; Becker, S. \& Kreilinger, V. (2018), Rights and Role of the European Parliament in Common Commercial Policy, Policy Paper no. 215, Jacques Delors Institut.

Woolcock, S. (2007), European Union Policy towards Free Trade Agreements, ECIPE Working Paper no. 03/2007.

Xie, T. (2006), 'Congressional roll call voting on China trade policy,' American Politics Research, vol. 34, no. 6, pp. 732-758. https://doi.org/10.1177/1532673X06289162 